\title{
Effect of Climate Change Resilience Strategies on Common Bacterial Blight of Common Bean (Phaseolus vulgaris L.) in Semi-arid Agro-ecology of Eastern Ethiopia
}

\author{
Negash Hailu ${ }^{1 *}$, Chemeda Fininsa1, Tamado Tana ${ }^{1}$ and Girma Mamo ${ }^{2}$ \\ ${ }^{1}$ School of Plant Sciences, Haramaya University, P.O.Box 138, Dire Dawa, Ethiopia \\ ${ }^{2}$ Melkasa Agricultural Research Institute, P.O. Box 436, Adama, Ethiopia
}

\begin{abstract}
Common bacterial blight (CBB) caused by Xanthomonas axonopodis pv. phaseoli is the most important biotic production constraint to common bean in eastern Ethiopia. Climate change could have an impact on the disease epidemiology by influencing both common bean growth and the pathogen reproduction. The effects of climate change needs to be mitigated using climate change resilience strategies. Field experiments were conducted in the 2012 and 2013 cropping seasons at Haramaya and Babile research stations in eastern Ethiopia to assess the effects of integrating climate change resilience strategies on CBB of common bean. Gofta (G2816) and Mexican 142(11239) common bean varieties were used. Eight climate change resilience strategies used were compost application, row intercropping and furrow planting alone and in combination. Factorial combinations of two common bean varieties and eight climate change resilience strategies totally 16 treatment combinations were studied in randomized complete block design (RCBD) with three replications and repeated once. Disease severity data were recorded from 10 randomly tagged plants from four central rows per plot. Disease severity, area under disease progress curve (AUDPC) and disease progress rate were significantly different among climate change resilience strategies, between varieties, cropping seasons and locations. Disease severities, AUDPC and disease progress rate were consistently less on row intercropping + compost application + furrow planting and row intercropping + compost application compared to singly applied climate change resilience strategies and sole planting plots in both locations and seasons. The disease epidemic was relatively higher on Mexican 142 than Gofta and during 2012 than 2013 at Babile than Haramaya. Integrated climate resilience strategies reduced CBB epidemics and could be applied as a component in management of CBB in eastern Ethiopia and in areas with similar agro-ecological zones.
\end{abstract}

Keywords: Climate Change Resilience, Phaseolus vulgaris, Xanthomonas axonopodis pv. phaseoli

\section{Introduction}

There are several biotic and abiotic production constraints on common bean (Phaseolus vulgaris L.) in semi-arid agro-ecologies of eastern Ethiopia. Diseases, insect pests, low soil fertility and periodic water stress are the major constraints $[1,2]$. The major diseases of common bean in the tropical regions, including Ethiopia that should be targeted for management are common bacterial blight (CBB) caused by Xanthomonas axonopodis pv. phaseoli, halo blight caused by Pseudomonas syringae pv. phaseolicola, bacterial brown spot caused by Pseudomonas syringae pv. syringae, rust caused by Uromyces appendiculatus, anthracnose caused by Colletotrichum lindemuthianum and other viral and root rot diseases [3-6]. These diseases are frequently occurring and widely distributed in Ethiopia and are destructive agents of common bean production causing heavy yield loss and decreasing seed quality [6-9].

Common Bacterial Blight (CBB) is one of the major diseases and the most important constraint to common bean production in eastern Ethiopia. When environmental conditions are favourable for the pathogen during long periods of warm and humid weather causing reductions $\mathrm{CBB}$ becomes the most destructive in both yield and seed quality [10]. Common bacterial blight incidence (53\%) and severity (63\%) were recorded in sole cropping system of common bean in eastern Ethiopia [8] and the relative yield loss of $22-40 \%$ was found in pure stand cropping system.

Change in rainfall pattern, soil moisture, soil temperature, and soil fertility has direct impact on the disease epidemiology by influencing host plant growth and susceptibility; pathogen reproduction, spread, survival, activity and host-pathogen interaction [11]. According to International Panel for Climate Change, the average global surface temperature will increase by $2.8^{\circ} \mathrm{C}$ ranging from 1.8 to $4.0^{\circ} \mathrm{C}$ during 2050 assuming no emission control policies. Climate models suggest that Ethiopia will see further warming in all seasons of $+2.2\left(1.4^{\circ} \mathrm{C}\right.$ $2.9^{\circ} \mathrm{C}$ ) by the $2050^{\prime} \mathrm{s}$ [12]. It is likely that this warming will be associated with higher heat waves and higher evapotranspiration rate. Nowadays, the doubt on climate change is not on its occurrence and effects, but rather on how to mitigate the ever-happening effects of climate change to manage properly crop production and protection to ensure food security of the ever-growing population and the proper functioning of the natural ecosystem. This needs to set resilience strategies that can mitigate the existing and ever happening effects of climate change.

The effect of increased temperature, rainfall variability and decreased soil moisture on plant diseases depend on the nature of their effects on both the host and the pathogens $[13,14]$. Those variables

*Corresponding author: Negash Hailu, School of Plant Sciences, Haramaya University, P.O.Box 138, Dire Dawa, Ethiopia, Tel: 251911850734; E-mail: negashhailu76@yahoo.com

Received October 08, 2015; Accepted October 27, 2015; Published November 02, 2015

Citation: Hailu N, Fininsa C, Tana T, Mamo G (2015) Effect of Climate Change Resilience Strategies on Common Bacterial Blight of Common Bean (Phaseolus vulgaris L.) in Semi-arid Agro-ecology of Eastern Ethiopia. Essential Oil. J Plant Pathol Microb 6: 310. doi:10.4172/2157-7471.1000310

Copyright: ( 2015 Hailu N, et al. This is an open-access article distributed under the terms of the Creative Commons Attribution License, which permits unrestricted use, distribution, and reproduction in any medium, provided the original author and source are credited. 
Citation: Hailu N, Fininsa C, Tana T, Mamo G (2015) Effect of Climate Change Resilience Strategies on Common Bacterial Blight of Common Bean (Phaseolus vulgaris L.) in Semi-arid Agro-ecology of Eastern Ethiopia. Essential Oil. J Plant Pathol Microb 6: 310. doi:10.4172/21577471.1000310

could first affect disease directly by changing the encounter rate between pathogens and hosts.

Because disease and environment are closely related, climate change may create favourable conditions for pathogens and alter the spatial and temporal distribution of disease epidemics [15]. The host plant agro-climate will be altered and pathogens will be affected negatively or positively [13]. To this effect, new diseases may arise in certain regions, and other diseases may cease to be economically important, especially when the host plant is introduced into new areas [15]. Pathogens tend to follow the host plant in their geographical distribution, but the rate at which pathogens become established in the new environment is a function of the mechanism of pathogen dispersal, suitability of the environment for dispersal, over seasoning, and physiological and ecological changes in the host plant [15]. Climate variability has the potential to modify host physiology and disease resistance and to change the stages and rates of pathogens development. The most likely impacts would be shifts in the spatial distribution of host and pathogen, changes in the physiology of host-pathogen interaction, alteration in crop loss and changes in the efficacy of management strategies [16,17]. Climate variability itself may be an important factor of pathogen selection pressure [13]

Inspite of crop diseases reducing crop productivity and food supply, there has been limited field based empirical research to assess the potential effect of climate change on plant disease $[11,17,18]$. Most research on how climate change influences plant disease has concentrated on the effects of one or two of the changing climatic factors on the host, pathogen, or the interaction of the two under controlled conditions that are very different from those in the real field. Other situational studies are based on modelling of data from controlled experiments [16].

Research in climate change related issues could result in improved understanding and management of crop diseases in the face of current and future climate extremes $[13,16]$. Understanding the effect of climate change resilience strategies such as plant nutrients through compost application $[19,20]$, soil and water conservation $[20,21]$, and species mixture combinations [8] management practices on disease intensities will assist identification of the most important variables and focus efforts in developing integrated management packages. The epidemics of CBB needs to be assessed under sole and integrated field based climate change resilience strategies such as intercropping, compost application and furrow planting. The objective of this study, therefore, was to assess the effects of climate change resilience strategies against CBB epidemiology of common bean in eastern Ethiopia.

\section{Materials and Methods}

\section{Experimental location}

Field experiments on $\mathrm{CBB}$ of common bean were conducted at Haramaya University experimental field stations at Babile and Haramaya, eastern Ethiopia during 2012 and 2013 main cropping seasons (June to November each year). Haramaya is located at $09^{\circ} 26^{\prime}$ $\mathrm{N}$ and $42^{\circ} 3^{\prime} \mathrm{E}$. The altitude of the area is 1980 meters above sea level with average annual rainfall of $786.8 \mathrm{~mm}$, mean minimum temperature of $10.4^{\circ} \mathrm{C}$, maximum temperature of $23.4^{\circ} \mathrm{C}$ and mean temperature of $16.8^{\circ} \mathrm{C}$. The soil of Haramaya is alluvial type with organic matter content of $6.8 \%$, total nitrogen of $0.34 \%$, available phosphorus of 2.2 $\mathrm{mg} \mathrm{kg} \mathrm{soil}{ }^{-1}, \mathrm{pH}$ of 7.13 with percent sand, silt and clay content of 62.9, 19.6 and 17.5 , respectively. Babile is situated at $09^{\circ} 13^{\prime} \mathrm{N}$ and $42^{\circ} 19^{\prime} \mathrm{E}$, with altitude of 1655 meters above sea level with annual total rainfall of $719.2 \mathrm{~mm}$. The mean minimum and maximum temperatures are
15.4 and $28.3^{\circ} \mathrm{C}$, respectively, with an average temperature of $21.83^{\circ} \mathrm{C}$. The soil of Babile is characterized with organic matter content of $2.95 \%$, total nitrogen of $0.1 \%$, available phosphorus of $1.28 \mathrm{mg} \mathrm{kg} \mathrm{soil}^{-1,} \mathrm{pH}$ of 6.6 with percent sand $45 \%$, silt $24 \%$ and clay $31 \%$.

Both locations represent important common bean growing areas and are conducive for $\mathrm{CBB}$ disease development of common bean. Babile is a representative of semi-arid agro ecology whereas Haramaya is a representative of midland agro ecology. The weather variables (mean maximum and minimum monthly temperature, monthly total rainfall) for 2012 and 2013 for both locations during experimental months are presented in Figure 1.

\section{Experimental design and management}

Three field based climate change resilience strategies such as compost application, row intercropping, and furrow planting were used solely and in combination (Table 1) in two common bean varieties Gofta (G2816) and Mexican 142 (G11239). Gofta is moderately resistant while Mexican 142 is susceptible to CBB. Sorghum variety, Teshale (3442-2OP) developed for the semi-arid environment as moisture stress and striga weed tolerant was used.

Totally 16 treatment combinations were arranged in a randomized complete block design in three replications on a plot size of $3.4 \mathrm{~m} \times 3.6$ $\mathrm{m}\left(12.24 \mathrm{~m}^{2}\right)$. Compost was applied two weeks before sowing at a rate of 8 tons per hectare, about half the rate recommended for cereals [22] for both crops. Compost was produced from the maize straw, teff straw and khat remaining $(3: 1: 2 \mathrm{~V} / \mathrm{V})$ ratio in well-prepared composting pits. The selection of proportions was based on the availability of crops remaining in the study area. The chops of those materials were watered and allowed to decompose for four months through intermittent mixing up. Its chemical properties were also analyzed.

Close-ended furrows were prepared by digging 20 centimeters deep rows two weeks before sowing in order to harvest the rainwater. Sorghum (variety Teshale) seeds were sown on 21 June 2012 and 28 June 2013 at Babile, 20 June 2012 and 02 July 2013 at Haramaya by drilling seeds at the seed rate of $5 \mathrm{Kg} \mathrm{ha}^{-1}$. Common bean seeds were sown on 11 July 2012 and 05 July 2013 at Babile, 07 July 2012 and 09 July 2013 at Haramaya manually by planting two seeds per hill. A standard intra and inter-row spacing for both crops were used according to the recommended spacing. Sorghum was planted in $0.8 \mathrm{~m}$ inter-row and $0.25 \mathrm{~m}$ intra-plant spacing. In row intercropping, a row of common bean was planted in the center of sorghum rows at $0.1 \mathrm{~m}$ intra-plant and $0.4 \mathrm{~m}$ inter-row spacing. Simultaneous planting was used in row intercropping. Similarly, in sole planting of common bean $0.4 \mathrm{~m}$ interrow and $0.1 \mathrm{~m}$ inter-plant spacing with 9 rows per plot were used. Spacing between blocks was $1.2 \mathrm{~m}$ and between plots was $1 \mathrm{~m} \mathrm{[23].}$

After emergence and establishment of seedlings, the rows were thinned to one plant per hill. Recommended agronomic practices such as hand weeding and hoeing were used for both crops [23]. Fertilizer application and artificial inoculation were not applied for common bean. Plants were hand weeded three times at Haramaya and two times at Babile and cultivated once during the growth periods at both locations and seasons.

\section{Disease data}

All disease data were collected from central four rows. Disease severity (leaf area showing characteristic CBB symptom) was assessed six times at an interval of seven days during the experimental periods beginning from 48-51 days after planting (DAP) until physiological maturity. Disease severity rating was performed on 10 randomly pre- 
(A)

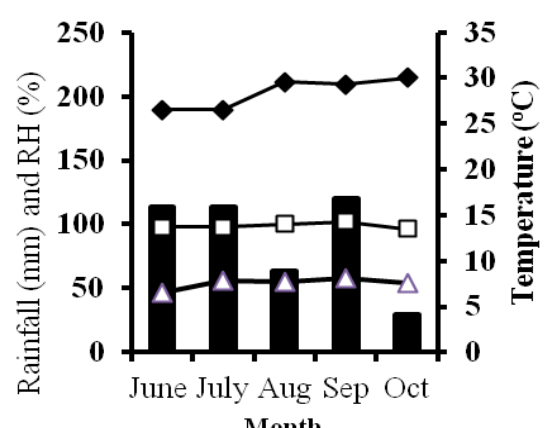

(c)

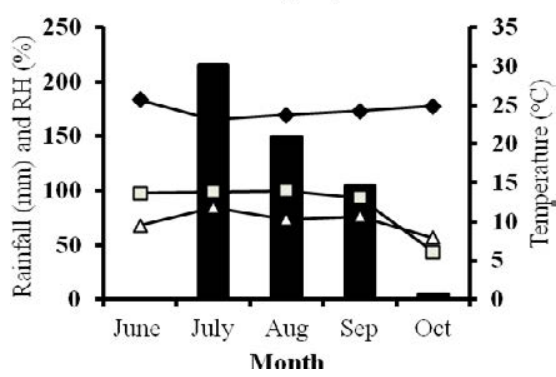

Rainfall (mm)

Maximum Temperature
(B)

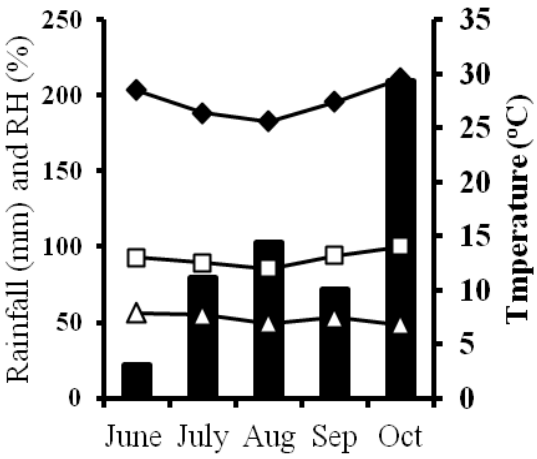

Month

(D)

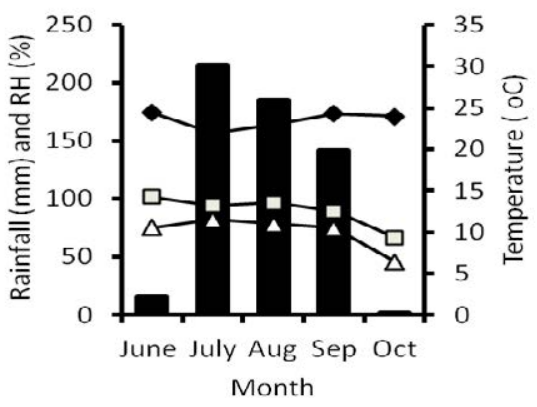

$\neg$ Relative humidity $(\%)$

$\rightarrow-$ Minimum temperature

Figure 1: The weather variables (mean maximum and mean minimum temperature $\left({ }^{\circ} \mathrm{C}\right)$, mean relative humidity $(\%)$ and total monthly rainfall (mm) at Babile in 2012. (A), in 2013. (B), at Haramaya in 2012. (C) and in 2013. (D).

\begin{tabular}{|l|l|l|}
\hline S. No & Treatment & Treatment combination description \\
\hline 1 & SP & sole planting \\
\hline 2 & CA & compost application \\
\hline 3 & FP & furrow planting \\
\hline 4 & RI & row intercropping \\
\hline 5 & CA+FP & row intercropping + furrow planting \\
\hline 6 & RI+CA & row intercropping + compost application \\
\hline 7 & RI+FP & row intercropping + furrow planting \\
\hline 8 & RI+CA+FP & row intercropping + compost application + furrow planting \\
\hline
\end{tabular}

Table 1: Climate change resilience treatments for management of common bean common bacterial blight for both Gofta and Mexican 142 varieties during 2012 and 2013 at Babile and Haramaya, eastern Ethiopia.

tagged plants per plot at both locations and seasons. Severity was rated using standard scales of 1-9 [24-26] where $1=$ no visible symptom and $9=$ disease covering more than $25 \%$ of the foliar tissue and the severity grades were converted into percentage severity index (PSI) for analysis using:

$$
\text { PSI }=\frac{\text { Sum of numerical ratings } \times 100}{\text { Number of plants scord } \times \text { maximum score on scale }}
$$

Area under disease progress curve (AUDPC) and disease progress rate $(r)$ were calculated from the severity data. AUDPC was computed from PSI data calculated on each date of assessment as described by Madden [27].

$$
\mathrm{AUDPC}=\sum_{\mathrm{i}=1}^{\mathrm{n}-1} 0.5(\mathrm{xi}+1+\mathrm{xi})(\mathrm{ti}+1-\mathrm{ti})
$$

Where $\mathrm{n}$ is the total number of assessments, $t_{i}$ is the time of the $i^{\text {th }}$ assessment in days from the first assessment date, $\mathrm{x}_{\mathrm{i}}$ is the percentage of disease severity at $\mathrm{i}^{\text {th }}$ assessment. AUDPC was expressed in percent-days because the severity $(\mathrm{x})$ was expressed in percent and time $(\mathrm{t})$ in days.

\section{Weather data}

Weather variables of minimum temperature $\left({ }^{\circ} \mathrm{C}\right)$ at $09: 00 \mathrm{~h}$ and maximum daily air temperature $\left({ }^{\circ} \mathrm{C}\right)$ at $18: 00 \mathrm{~h}$, relative humidity $(\%)$ at 06:00 h, 09:00 h, 12:00 h, 15:00 $\mathrm{h}$ and 18:00 h, and daily rainfall $(\mathrm{mm})$ were collected from the meteorological stations of both location and the averages were calculated and presented in Figure 1.

\section{Data analysis}

Mean disease severity and yield data from each variety and treatment were examined and used for data analysis. Disease severity at different DAP and AUDPC were subjected to analysis of variance using the PROC GLM procedure of AUDPC or SAS version 9.1 [28] to determine the treatment effects. Homogeneity of variances was tested using the procedure described by Gomez and Gomez [29] and as the test showed heterogeneity of variances, separate analysis of the two-year and two location data was performed. Differences among treatment means were compared using the Fisher's least significant difference (LSD) test at $5 \%$ level of significance. 
Citation: Hailu N, Fininsa C, Tana T, Mamo G (2015) Effect of Climate Change Resilience Strategies on Common Bacterial Blight of Common Bean (Phaseolus vulgaris L.) in Semi-arid Agro-ecology of Eastern Ethiopia. Essential Oil. J Plant Pathol Microb 6: 310. doi:10.4172/21577471.1000310

\section{Results}

\section{Disease severity}

Common bacterial blight epidemics on both varieties during both cropping seasons were varied significantly among the climate change resilience strategies. Disease severity was consistently less on the most integrated plots than sole planted and less integrated plots. During both cropping seasons, the disease severity was significantly different $(\mathrm{P}<0.01)$ among climate change resilience strategies throughout the whole disease recording dates while significant difference $(\mathrm{P}<0.01)$ of disease severity between the two varieties were recorded at late disease recording days. A higher disease severity was observed in the year 2012 compared with the 2013 cropping season. The interaction between and among the climate change resilience strategies, varieties and location was not significant.

In 2012, the highest initial disease severity (18.5\%) at 48 DAP was calculated from sole planted plots of Gofta variety, while lower was recorded in row intercropping + compost application plots of common bean varieties at Babile (Figure 2). Similarly, higher final disease severity at 83 DAP was recorded from sole planting on Mexican 142 (54\%) and on Gofta (53.8\%) whereas lower final disease severity was recorded from row intercropping + compost application + furrow plating on Gofta (40\%) and from row intercropping + compost application on Mexican 142 (40.7\%) (Figure 2). During the 2013 cropping season, higher final disease severities at $85 \mathrm{DAP}$ on Gofta (43\%) and on Mexican 142 (50.4\%) were obtained from sole planting while lower final disease severity on Gofta $(27.4 \%)$ was obtained from row intercropping + compost application and on Mexican 142 (38.2\%) from row intercropping + compost application + furrow planting at Babile (Figure 2). The other climate change resilience strategies reduced $\mathrm{CBB}$ severity intermediately and showed similar trend of disease reduction form the first to last date of disease recording and the data were not presented in the Figure 2 for clarity.
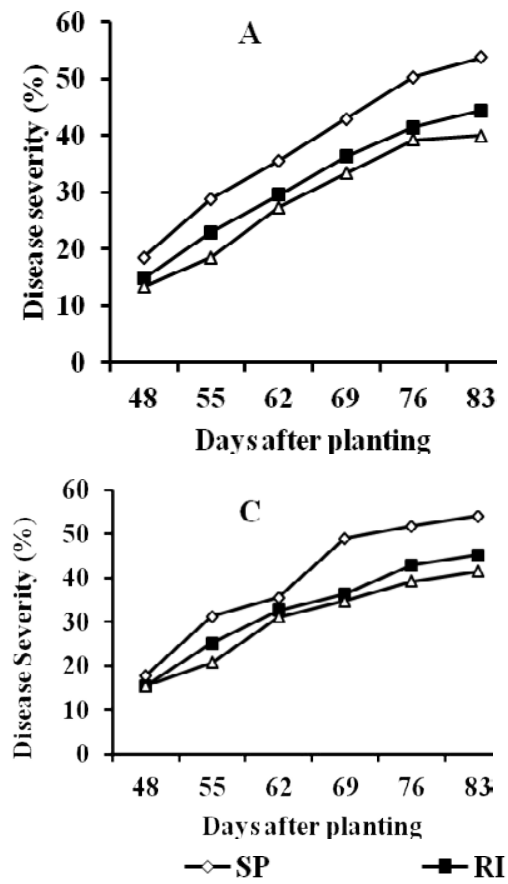
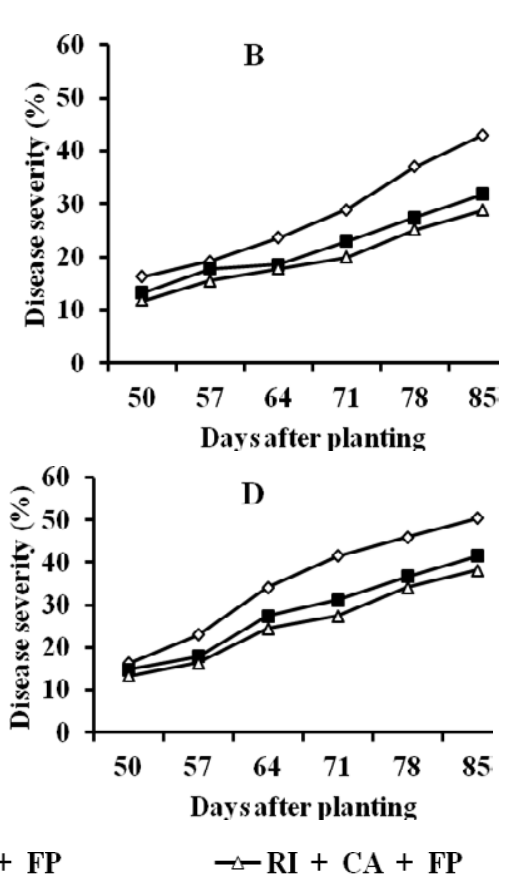

Figure 2: Disease progress curve of common bean common bacterial blight on (A) Gofta in 2012 (B) Gofta in 2013, (C) Mexican 142 in 2012 and (D) Mexican 142 in 2013 at Babile. RI + CA + FP, row intercropping + compost application + furrow planting; RI + FP, row intercropping + furrow planting; SP, sole planting.

At Haramaya, the highest initial disease severity (20\%) at 50 DAP was calculated from sole planted plots of Gofta variety, while lower was recorded in row intercropping + compost application + furrow planting plots of Gofta and in row intercropping of Mexican 142 in 2012 cropping season (Figure 3). Similarly, higher final disease severity at 85 DAP was recorded from sole planting on Mexican 142 (56\%) and on Gofta (48\%) whereas lower final disease severity was recorded from row intercropping + compost application on Gofta (40\%) and from row intercropping + compost application + furrow planting on Mexican 142 (42.9\%). During the 2013 cropping season, higher final disease severities at 86 DAP on Gofta (43\%) and on Mexican 142 (54.8\%) were obtained from sole planting followed by furrow planting while lower final disease severity on Gofta (28\%) and on Mexican 142 (40\%) were obtained from row intercropping + compost application + furrow planting at Haramaya (Figure 3). The other climate change resilience strategies reduced CBB severity intermediately and showed similar trend of disease reduction form the first to last date of disease recording and the data were not presented in the Figure for clarity.

With respect to mean initial and final disease severity of the varieties during 2012 cropping season, the highest mean initial disease severity was $18.2 \%$ at Babile and $19.6 \%$ at Haramaya in sole planting (Table 2). The row intercropping + compost application had the lowest $13.3 \%$ at Babile and row intercropping + furrow planting had the lowest (14.1 \%) mean initial disease severity at Haramaya (Table 2). The highest mean final disease severity (53.9\%) was recorded in sole planting at Babile and $52.4 \%$ at Haramaya (Table 2). The lowest mean final disease severity was from row intercropping + compost application + furrow planting (40.7\%) at Babile (Table 2) and $41.8 \%$ at Haramaya during 2012 (Table 2).

During 2013 cropping season, the highest mean initial disease severity at 50 DAP was $16.3 \%$ in sole planting at Babile and at 51 DAP was $17.8 \%$ in sole planting at Haramaya, while the row intercropping 
Citation: Hailu N, Fininsa C, Tana T, Mamo G (2015) Effect of Climate Change Resilience Strategies on Common Bacterial Blight of Common Bean (Phaseolus vulgaris L.) in Semi-arid Agro-ecology of Eastern Ethiopia. Essential Oil. J Plant Pathol Microb 6: 310. doi:10.4172/21577471.1000310
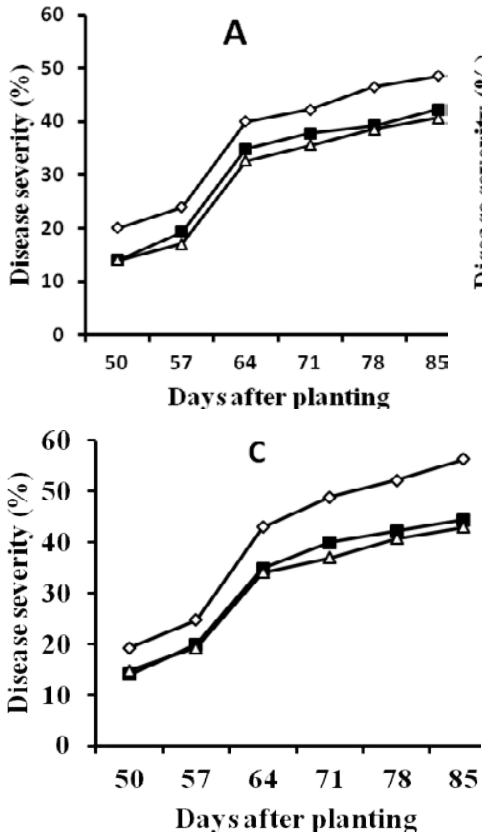

$\sim-\infty P$

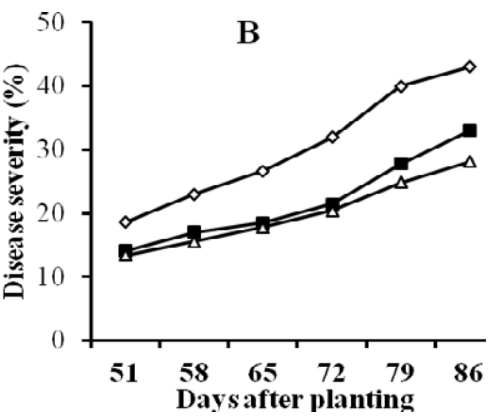

D

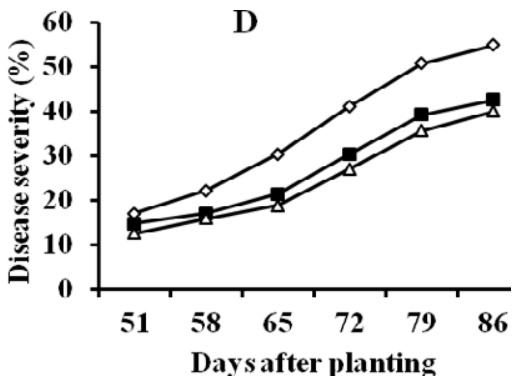

$\rightarrow-\mathrm{RI}+\mathrm{CA}+\mathrm{FP}$

Figure 3: Disease progress curve of common bean common bacterial blight on (A) Gofta in 2012 (B) Gofta in 2013, (C) Mexican 142 in 2012 and (D) Mexican 142 in 2013 at Haramaya. RI + CA + FP, row intercropping + compost application + furrow planting; RI + FP, row intercropping + furrow planting; SP, sole planting.

\begin{tabular}{|c|c|c|c|c|c|c|c|c|}
\hline \multirow{3}{*}{$\begin{array}{c}\text { Location } \\
\text { Year } \\
\text { PSI }\end{array}$} & \multicolumn{4}{|c|}{ Babile } & \multicolumn{4}{|c|}{ Haramaya } \\
\hline & \multicolumn{2}{|c|}{2012} & \multicolumn{2}{|c|}{2013} & \multicolumn{2}{|c|}{2012} & \multicolumn{2}{|c|}{2013} \\
\hline & Initial & Final & Initial & Final & Initial & Final & Initial & Final \\
\hline \multicolumn{9}{|l|}{ Variety } \\
\hline Mexican 142 & $15.8 a$ & $47.5 a$ & $15.3 a$ & $42.7 a$ & $15.8 a$ & $48.7 a$ & $15.2 \mathrm{a}$ & $47.2 a$ \\
\hline Gofta & $15.1 \mathrm{a}$ & $46.8 a$ & $13.9 b$ & $34.1 \mathrm{~b}$ & $15.8 \mathrm{a}$ & $43.4 \mathrm{~b}$ & $15.1 \mathrm{a}$ & $34.3 b$ \\
\hline LSD (0.05) & 1.32 & 1.59 & 1.04 & 2.26 & 1.28 & 2.42 & 1 & 2.1 \\
\hline \multicolumn{9}{|l|}{ Strategy } \\
\hline SP & $18.2 a$ & $53.9 a$ & $16.3 a$ & $46.7 a$ & $19.6 a$ & $52.4 a$ & $17.8 \mathrm{a}$ & $48.9 a$ \\
\hline $\mathrm{CA}$ & $14.8 \mathrm{c}$ & $51.0 \mathrm{ab}$ & $15.6 a b$ & $39.3 b c$ & $17.4 \mathrm{ab}$ & $52.8 a$ & $16.3 a b$ & $46.3 a b$ \\
\hline FP & $17.8 \mathrm{ab}$ & $51.1 \mathrm{ab}$ & $15.9 a b$ & $42.6 a b$ & $16.7 \mathrm{bc}$ & $44.8 b c$ & $15.7 \mathrm{~b}$ & $43.3 \mathrm{bc}$ \\
\hline $\mathrm{RI}$ & $15.2 b c$ & $44.6 \mathrm{~cd}$ & $14.4^{\mathrm{abcd}}$ & $36.7 \mathrm{~cd}$ & $14.4 \mathrm{~cd}$ & $44.1 b c$ & $14.4 \mathrm{bc}$ & 38.0de \\
\hline $\mathrm{CA}+\mathrm{FP}$ & $14.8 \mathrm{c}$ & $49.7 b$ & $14.8 \mathrm{abc}$ & $38.5 b c$ & 15.bcd & $47.0 \mathrm{~b}$ & $15.9 a b$ & $41.3 \mathrm{~cd}$ \\
\hline $\mathrm{RI}+\mathrm{CA}$ & $13.3 c$ & 41.5de & $12.9 \mathrm{~cd}$ & $33.2 \mathrm{~d}$ & $14.8 \mathrm{~cd}$ & $41.8 c$ & $13.7 \mathrm{c}$ & $36.1 \mathrm{e}$ \\
\hline $\mathrm{RI}+\mathrm{FP}$ & $15.2 b c$ & $44.8 \mathrm{c}$ & 14.1bcd & $36.7 \mathrm{~cd}$ & $14.1 d$ & $43.3 b c$ & $14.4 \mathrm{bc}$ & 37.8de \\
\hline $\mathrm{RI}+\mathrm{CA}+\mathrm{FP}$ & $14.4 \mathrm{c}$ & $40.7 \mathrm{e}$ & $12.6 \mathrm{~d}$ & $33.5 \mathrm{~d}$ & $14.4 \mathrm{~cd}$ & $41.8 c$ & $13.0 \mathrm{c}$ & $34.1 \mathrm{e}$ \\
\hline LSD (0.05) & 2.65 & 3.18 & 2.07 & 4.52 & 2.55 & 4.83 & 2 & 4.2 \\
\hline CV (\%) & 14.5 & 5.71 & 12.05 & 9.99 & 13.68 & 8.91 & 11.2 & 8.7 \\
\hline
\end{tabular}

$\mathrm{PSI}=$ percentage severity index, $\mathrm{LSD}=\mathrm{Least}$ Significant difference, $\mathrm{CV}=$ Coefficient of Variance, $\mathrm{CV}=\mathrm{Coefficient}$ of variation, $\mathrm{CA}=\mathrm{compost}$ application, $\mathrm{FP}=\mathrm{furrow}$ planting, $\mathrm{RI}=$ row intercropping, $\mathrm{CA}+\mathrm{FP}=$ compost application + furrow planting, $\mathrm{RI}+\mathrm{CA}=$ row intercropping + compost apllication, $\mathrm{RI}+\mathrm{FP}=$ row-intercropping + furrow planting, $\mathrm{RI}$ $+\mathrm{CA}+\mathrm{FP}=$ row intercropping + compost application + furrow planting, $\mathrm{SP}=$ sole planting.

Table 2: Effects of integrated climate change resilience strategies on CBB disease severity at Babile and Haramaya during 2012 and 2013 cropping seasons.

+ compost application + furrow planting had the lowest mean initial disease severity $12.6 \%$ at Babile and $13 \%$ at Haramaya (Table 2 ). The highest mean final disease severity at 85 DAP (46.7\%) was recorded in sole planting at Babile and at 86 DAP was $48.9 \%$ at Haramaya while the lowest mean final disease severity was from row intercropping + compost application + furrow planting (33.5\%) at Babile and $34.1 \%$ at Haramaya (Table 2).

In both cropping seasons while CBB occurred on both varieties it did not vary at early stage. However, significant variations in the disease severity between varieties started from 55 to 69 DAP at Babile and from 64 to 83 DAP at Haramaya during 2012, whereas 50 to 85 DAP at Babile and 65 to 86 DAP at Haramaya during 2013 (Figure 3). At both locations and during both cropping seasons significantly higher disease severity was recorded from Mexican 142 than Gofta variety. Likewise, higher mean initial disease severity $(15.8 \%, 15.3 \%)$ and final disease severity $(45.5 \%, 42.7 \%)$ were recorded on Mexican 142, during 2012 and 2013 respectively than on Gofta variety at Babile (Table 2).

Considering the range of disease severity and percentage of 
Citation: Hailu N, Fininsa C, Tana T, Mamo G (2015) Effect of Climate Change Resilience Strategies on Common Bacterial Blight of Common Bean (Phaseolus vulgaris L.) in Semi-arid Agro-ecology of Eastern Ethiopia. Essential Oil. J Plant Pathol Microb 6: 310. doi:10.4172/21577471.1000310

disease severity reduction, the solely applied climate change resilience strategies had higher disease severity and lower reduction compared to most integrated and integrated ones. The most integrated climate change resilience strategy i.e. row intercropping + compost application + furrow planting and row intercropping + compost application caused higher CBB severity reduction. The resilience strategies reduced the mean final disease severity of both varieties from $5.2-24.5 \%$ (mean 14.3\%) during 2012 at Babile (Table 2). Similarly, the resilience strategies reduced the mean final disease severity from $12.1-34.5 \%$ (mean 20.3\%) on Gofta (Figure 3B) and from 10.8-27\% (mean 13.9\%) on Mexican 142 (Figure 3D) at Haramaya during 2013.

\section{Area under disease progress curve}

There were significant differences $(\mathrm{P}<0.001)$ among the climate change resilience strategies in both locations and seasons for mean AUDPC (Figures 4 and 5). There was significant difference $(\mathrm{P}<0.01)$ between the two varieties of common bean, with the mean AUDPC value (1230\%-days) higher on the Mexican 142 variety than Gofta (1158\%-days) during 2012 cropping season and mean AUDPC value (1041\%-days) higher on the Mexican 142 variety than Gofta (807\%days) during 2013 at Babile. At Haramaya, the mean AUDPC value (1253\%-days) was higher on Mexican 142 variety than (1153\%-days) on Gofta during 2012 cropping season and mean AUDPC value was higher (1057\%-days) on Mexican 142 variety than (822\%-days) on Gofta during 2013.

At Babile, highest AUDPC The values were obtained from sole planting of Gofta and Mexican 142, respectively. The lowest AUDPC value was computed from row intercropping + compost application + furrow planting on Gofta and from row intercropping + compost application on Mexican 142, during 2012 (Figure 4A) .The row intercropping + compost application + furrow planting reduced the AUDPC value by $25 \%$ on Gofta and row intercropping + compost application reduced AUDPC value by $26.3 \%$ on Mexican 142. During 2013 cropping season, on Mexican 142 variety maximum AUDPC value (1244.5\%-days) was computed from the sole planting whereas the minimum value (895.9\%-days) was from row intercropping + compost application + furrow planting plots followed by row intercropping + compost application (908.7\%-days) at Babile (Figure 5A). The resilience strategies reduced AUDPC values from 6.4-30.8\% (mean 16.8\%) on
Gofta and from 8.7-28\% (mean 16.3\%) on Mexican 142 compared to sole planting during 2013 cropping season at Babile (Figure 5A).

At Haramaya during 2012, the maximum AUDPC value was computed from the sole planting on Mexican 142 and the minimum value from row intercropping + compost application + furrow planting followed by row intercropping + compost application (Figure 4B). In the same year, on Gofta variety, row intercropping + compost application + furrow planting reduced AUDPC by $19.2 \%$, row intercropping + compost application by $19.1 \%$ compared to sole planting whereas row intercropping + compost application + furrow planting reduced AUDPC by $22.6 \%$, row intercropping + compost application by $21.7 \%$ and row intercropping + furrow planting by $19.5 \%$ compared to sole planting on Mexican 142. The climate change resilience strategies reduced AUDPC value by $6-19 \%$ (mean $11.9 \%$ ) on Gofta and 10.6$22.6 \%$ (mean 13.4\%) on Mexican 142 compared to sole planting during 2012 cropping season at Haramaya.

Higher AUDPC Values were recorded from sole planting of Gofta and Mexican 142 respectively, while lowest AUDPC value on Mexican 142 form row intercropping + compost application + furrow planting during 2013 (Figure 5B). Therefore, row intercropping + compost application + furrow planting reduced the AUDPC values by $34.8 \%$ on Gofta and by $31.4 \%$ on Mexican 142. All of climate change resilience strategies reduced AUDPC by 16.8-34.8\% (mean 22.9\%) on Gofta and 11.4-31.4\% (mean 16.3\%) on Mexican 142 compared to sole planting during 2013 cropping season at Haramaya.

\section{Disease progress rate}

Comparisons of disease progress rates were made among treatments based on the Logistic model by fitting disease severity data with dates of assessment. The rates of disease progress were varied among treatments, between locations and seasons. During 2012 cropping season, the highest disease progress rate $\left(0.055\right.$-logit day $\left.{ }^{-1}\right)$ was computed from Mexican 142 variety at Haramaya while the lowest epidemic rate $\left(0.027 \operatorname{logit}\right.$ day $\left.^{-1}\right)$ was from Gofta variety during 2013 cropping season at Haramaya. The disease progress rates calculated for varieties, climate change resilience strategies, years and locations were different and presented in Table 3 for 2012 and Table 4 for 2013 seasons. During both cropping seasons, the reduction of disease progress rate

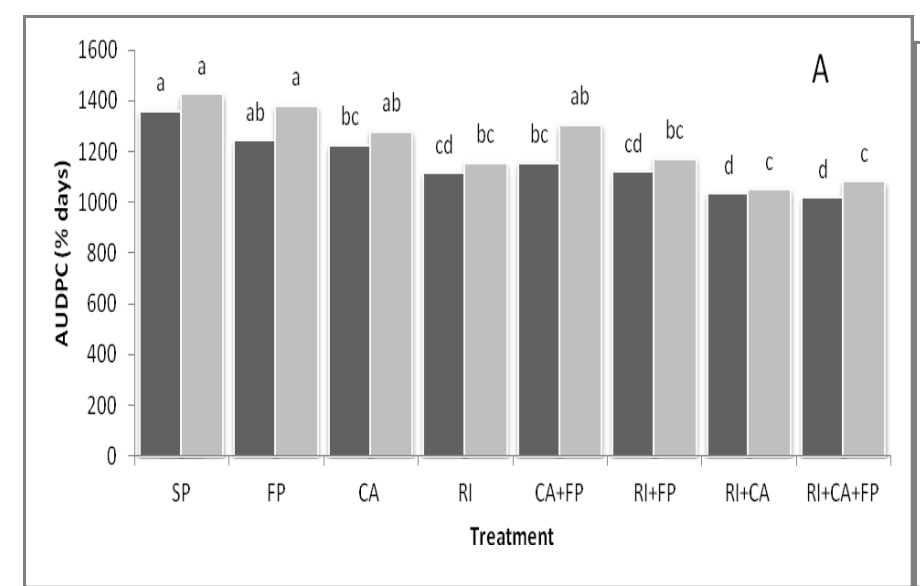

- Gofta

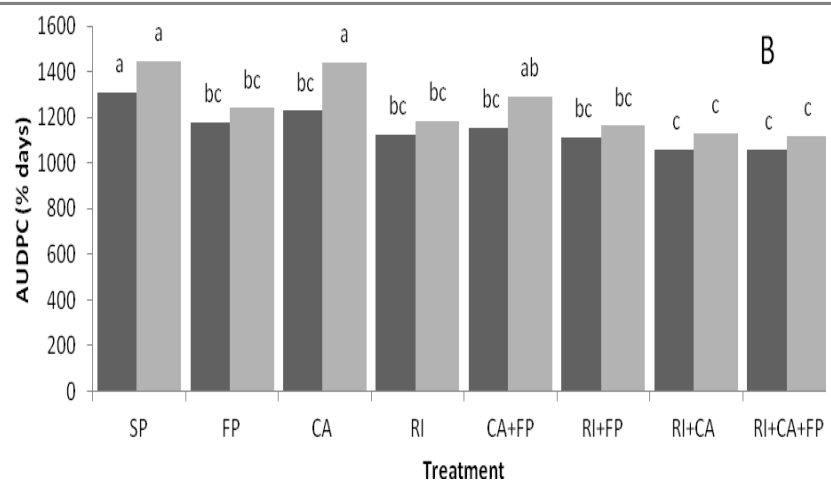

Mexican 142

Figure 4: Area under disease progress curve of common bean common bacterial blight on Gofta and Mexican 142 during 2012 (A) at Babile and (B) at Haramaya. FP, furrow planting; RI, row intercropping; CA, compost application; CA + FP, compost application + furrow planting; RI + FP, row-intercropping + furrow planting; RI + CA + FP, row intercropping + compost application + furrow planting; RI + CA, row intercropping+compost apllication; SP, sole planting. 
Citation: Hailu N, Fininsa C, Tana T, Mamo G (2015) Effect of Climate Change Resilience Strategies on Common Bacterial Blight of Common Bean (Phaseolus vulgaris L.) in Semi-arid Agro-ecology of Eastern Ethiopia. Essential Oil. J Plant Pathol Microb 6: 310. doi:10.4172/21577471.1000310

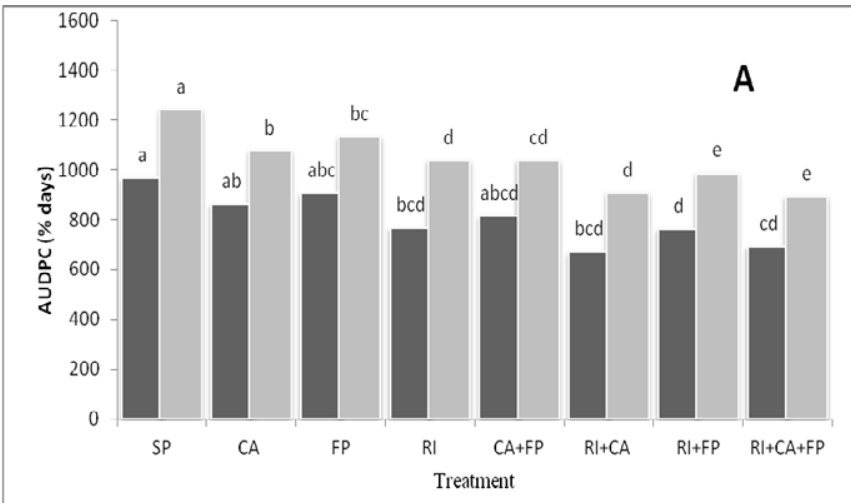

- Gofta

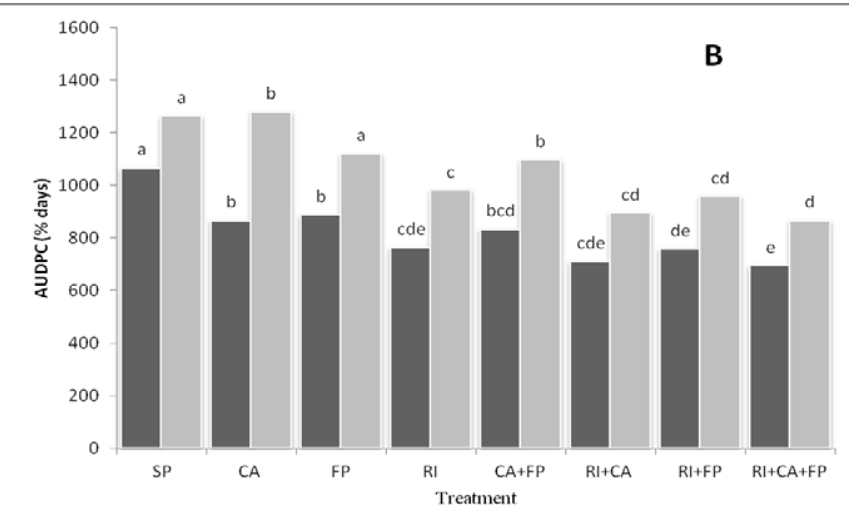

Mexican 142

Figure 5: Area under disease progress curve of common bean common bacterial blight on Gofta and Mexican 142 during 2013 (A) at Babile and (B) at Haramaya. FP, furrow planting; RI, row intercropping; CA, compost application; CA + FP, compost application + furrow planting; RI + FP, row-intercropping + furrow planting; RI + CA + FP, row intercropping + compost application + furrow planting; RI + CA, row intercropping+compost apllication; SP, sole planting.

achieved through application of climate change resilience strategies have shown similar trend to the disease severity and area under disease progress curve in both varieties and locations.

In the 2012 cropping season, the disease progress rate was higher on the Gofta ( 0.053 logit day $\left.{ }^{-1}\right)$ treated with compost application, on Mexican $142\left(0.050\right.$ logit day $\left.{ }^{-1}\right)$ treated with compost application + furrow planting at Babile and on Mexican (0.055 logit day $\left.{ }^{-1}\right)$ treated with compost application, at Haramaya (Table 3). Application of row intercropping + furrow planting reduced disease progress rate by $6.5 \%$ on Gofta and application of row intercropping + compost application + furrow planting reduced disease progress rate by $18.7 \%$ on Mexican 142 compared to sole planting at Babile during 2012 cropping season (Table $3)$. Lower rate of disease progress was obtained from row intercropping + compost application on Gofta $\left(0.040 \operatorname{logit}_{\text {day }}{ }^{-1}\right)$ and from row intercropping + compost application + furrow planting on Mexican 142 $\left(0.44\right.$ logit day $\left.^{-1}\right)$. Generally, application of row intercropping + compost application + furrow planting reduced the rate of disease progress by $12 \%$ on Mexican 142 variety at Haramaya during 2012.

In 2013 cropping season, slower disease progress rate was calculated on Gofta (0.029 logit day- $\left.{ }^{-1}\right)$ and on Mexican $142(0.037$ logit day $\left.{ }^{-1}\right)$ treated with row intercropping + compost application at Babile and on Gofta $\left(0.027\right.$ logit day $\left.{ }^{-1}\right)$ and on Mexican 142 (0.046 logit day $\left.^{-1}\right)$ treated with row intercropping + compost application + furrow planting at Haramaya compared to sole planting. In 2013 the disease progress rate from compost application was faster $\left(0.055\right.$ logit day $\left.{ }^{-1}\right)$ than the remaining climate change resilience strategies on Mexican 142 (Table 4), and sole planting had faster disease progress rate $(0.04$ logit day $\left.{ }^{-1}\right)$ on Gofta and (0.048 logit day ${ }^{-1)}$ on Mexican 142 at Babile. The disease progress rate in compost application was highest in both cropping seasons on Mexican 142 at Haramaya. Application of the most integrated climate change resilience strategy: row intercropping + compost application + furrow planting reduced the rate of disease progress by $22.9 \%$ on Gofta variety and by $14.8 \%$ on Mexican variety during 2013 cropping season at Haramaya (Table 4).

\section{Discussion}

Common bacterial blight epidemics significantly varied among and between climate change resilience strategies, between common bean varieties, locations and cropping seasons. Variety Mexican 142 had higher disease severity and higher area under disease progress curve (AUDPC) than variety Gofta might be due to the higher resistance level of Gofta than Mexican 142. The result of this study agreed with the findings of Fininsa and Tefera [9] that described Gofta as moderately resistant to common bacterial blight and Mexican 142 as susceptible variety. Higher disease epidemic was found during 2012 cropping season than 2013 cropping season at both locations. In both location higher relative humidity, higher minimum and maximum temperatures (Figure 1) recorded in August and September months during 2012 cropping season could have created conducive environment for increased common bacterial blight severity and progress rate than 2013 cropping season. Similarly, lower relative humidity, higher minimum and maximum temperatures were recorded at Babile than at Haramaya during both cropping seasons (Figure 1), were suitable for common bacterial blight disease development and early disease appearance common bacterial blight. At Haramaya, lower disease severity and lower AUDPC were computed than at Babile during both cropping seasons. The result was similar with the findings of Fininsa [8] as high temperature and low relative humidity favor higher common bacterial blight severity.

Climate change resilience strategies had lower final disease severity (8.6-36.2\%) and lower AUDPC than the sole planting on both varieties of common bean during 2012 and 2013 cropping seasons at both locations. The variation of final disease severity was based on the type of climate change resilience strategy, resistance level of common bean, common bacterial blight conduciveness of location and weather variables of two cropping seasons.

Intercropping common bean with sorghum has significantly lowered the severity level of common bacterial blight compared with sole planting. Row intercropping + compost application + furrow planting and row intercropping + compost application showed significantly lower common bacterial blight severity than the sole plantings during both cropping seasons and locations. All types of common bean-sorghum intercropping systems (row intercropping, row intercropping + furrow planting, row intercropping + compost application, row intercropping + compost application + furrow planting) significantly reduced the final disease severity (13-36.2\%) 
Citation: Hailu N, Fininsa C, Tana T, Mamo G (2015) Effect of Climate Change Resilience Strategies on Common Bacterial Blight of Common Bean (Phaseolus vulgaris L.) in Semi-arid Agro-ecology of Eastern Ethiopia. Essential Oil. J Plant Pathol Microb 6: 310. doi:10.4172/21577471.1000310

Page 8 of 10

\begin{tabular}{|c|c|c|c|c|c|c|c|c|}
\hline \multirow{3}{*}{$\begin{array}{l}\text { Resilience } \\
\text { strategy }\end{array}$} & \multicolumn{4}{|c|}{ Babile } & \multicolumn{4}{|c|}{ Haramaya } \\
\hline & \multicolumn{2}{|c|}{ Gofta } & \multicolumn{2}{|c|}{ Mexican } & \multicolumn{2}{|c|}{ Gofta } & \multicolumn{2}{|c|}{ Mexican } \\
\hline & Rate $(r)$ & $\mathbf{R}^{2}$ & Rate $(r)$ & $\mathbf{R}^{2}$ & Rate $(r)$ & $\mathbf{R}^{2}$ & Rate $(r)$ & $\mathbf{R}^{2}$ \\
\hline SP & 0.046 & 90.8 & 0.048 & 88.4 & 0.04 & 83.7 & 0.05 & 83.1 \\
\hline $\mathrm{CA}$ & 0.053 & 92.7 & 0.048 & 89.9 & 0.043 & 81.7 & 0.055 & 86.9 \\
\hline $\mathrm{FP}$ & 0.046 & 89.7 & 0.046 & 87 & 0.04 & 79 & 0.044 & 82.1 \\
\hline RI & 0.046 & 89.3 & 0.042 & 86.9 & 0.042 & 82 & 0.049 & 84.2 \\
\hline$C A+F P$ & 0.05 & 93.9 & 0.05 & 84.6 & 0.042 & 79.5 & 0.052 & 85.1 \\
\hline $\mathrm{RI}+\mathrm{CA}$ & 0.048 & 87.8 & 0.044 & 84.1 & 0.04 & 81.2 & 0.045 & 83.8 \\
\hline $\mathrm{RI}+\mathrm{FP}$ & 0.043 & 87.6 & 0.041 & 86.5 & 0.043 & 79 & 0.046 & 84.2 \\
\hline $\mathrm{RI}+\mathrm{CA}+\mathrm{FP}$ & 0.044 & 86.7 & 0.039 & 86 & 0.044 & 80.8 & 0.044 & 82.7 \\
\hline
\end{tabular}

$\mathrm{CA}=$ compost application, $\mathrm{FP}=$ furrow planting, $\mathrm{RI}=$ row intercropping, $\mathrm{CA}+\mathrm{FP}=$ compost application + furrow planting, $\mathrm{RI}+\mathrm{CA}=$ row intercropping + compost apllication, $\mathrm{R}$ $+F P=$ row-intercropping + furrow planting, $\mathrm{RI}+\mathrm{CA}+\mathrm{FP}=$ row intercropping + compost application + furrow planting, $\mathrm{SP}=$ sole planting.

Table 3: Common bean common bacterial blight disease progress rate $(r)$ in logit per day and adjusted coefficient of determination $\left(R^{2}\right)$ on $G$ ofta and Mexican 142 varieties at Babile and Haramaya during 2012 cropping season.

\begin{tabular}{|c|c|c|c|c|c|c|c|c|}
\hline \multirow{3}{*}{$\begin{array}{c}\text { Resilience } \\
\text { strategy }\end{array}$} & \multicolumn{4}{|c|}{ Babile } & \multicolumn{4}{|c|}{ Haramaya } \\
\hline & \multicolumn{2}{|c|}{ Gofta } & \multicolumn{2}{|c|}{ Mexican } & \multicolumn{2}{|c|}{ Gofta } & \multicolumn{2}{|c|}{ Mexican } \\
\hline & Rate (r) & $\mathbf{R}^{2}$ & Rate (r) & $\mathbf{R}^{2}$ & Rate (r) & $\mathbf{R}^{2}$ & Rate (r) & $\mathbf{R}^{2}$ \\
\hline SP & 0.04 & 90.3 & 0.048 & 90.1 & 0.035 & 91 & 0.054 & 93.3 \\
\hline CA & 0.034 & 83.5 & 0.041 & 86.2 & 0.033 & 80.1 & 0.055 & 95.3 \\
\hline FP & 0.037 & 87.2 & 0.044 & 88.5 & 0.036 & 84.7 & 0.048 & 93.4 \\
\hline RI & 0.031 & 77.9 & 0.041 & 89.7 & 0.029 & 82.1 & 0.047 & 90.4 \\
\hline $\mathrm{CA}+\mathrm{FP}$ & 0.036 & 83.6 & 0.039 & 88.2 & 0.033 & 85.9 & 0.048 & 89.2 \\
\hline $\mathrm{RI}+\mathrm{CA}$ & 0.029 & 87.6 & 0.037 & 69 & 0.028 & 78.5 & 0.048 & 88.4 \\
\hline $\mathrm{RI}+\mathrm{FP}$ & 0.03 & 77.6 & 0.042 & 92.9 & 0.031 & 82.9 & 0.046 & 88.8 \\
\hline $\mathrm{RI}+\mathrm{CA}+\mathrm{FP}$ & 0.031 & 86.1 & 0.041 & 90.7 & 0.027 & 82.9 & 0.046 & 91.1 \\
\hline
\end{tabular}

$\mathrm{CA}=$ compost application, $\mathrm{FP}=$ furrow planting, $\mathrm{RI}=$ row intercropping, $\mathrm{CA}+\mathrm{FP}=$ compost application + furrow planting, $\mathrm{RI}+\mathrm{CA}=$ row intercropping + compost apllication, $\mathrm{RI}$ $+F P=$ row-intercropping + furrow planting, $\mathrm{RI}+\mathrm{CA}+\mathrm{FP}=$ row intercropping + compost application + furrow planting, $\mathrm{SP}=$ sole planting.

Table 4: Common bean common bacterial blight disease progress rate $(r)$ in logit per day and coefficient of determination $\left(R^{2}\right)$ on $G$ ofta and Mexican 142 varieties at Babile and Haramaya during 2013 cropping season.

and AUDPC compared to sole planted plots at both locations and seasons. Similarly, Fininsa [8] reported reduction of $17-40 \%$ common bacterial blight severity in bean-maize intercropping. In sorghum-common bean intercropping, common bacterial blight disease epidemics were reduced because the sorghum may be used as physical barrier against bacterial inoculum from reaching to common bean. Changes in microclimate such as temperature and wind velocity reduction may disfavor the pathogen and cause reduction in disease. Higher temperature and relative humidity are favorable conditions for common bacterial blight disease epidemics and a decrease in temperature in the intercropping system might have lowered the severity of common bacterial blight. A cool microclimate in row intercropping + compost application + furrow planting disfavours common bacterial blight pathogen infection that could be initiated from infected seeds, infested soil or infested debris in the soil. The microclimate may also retard proliferation and spread of the bacteria between plants as the result of non-host nature of component crop sorghum for the bacteria.

Intercropping common bean with sorghum therefore could have been reduced the common bacterial blight severity and AUDPC compared to sole planting, during 2012 and 2013 cropping seasons at both location. In addition to disfavor common bacterial blight severity, intercropping can maintain soil fertility and balanced nutrition that might be the case for physiological and morphological fitness of the crop to build resistance to common bacterial blight. The result of this study is in line with the report of Matusso, et al. [30] that the principal reasons for intercropping are soil conservation and improvement of soil fertility, diseases control and balanced nutrition.
Furrow planting reduced the final disease severity during both cropping seasons at both locations when applied singly (2.7-18.4\%) or in combination (5.7-34.5\%) with other resilience strategies such as compost application and intercropping. Furrow planting could conserve soil moisture and create sufficient water availability in the root system of common bean that might have enabled common bean to reduce disease epidemics due to creation suitable condition for plants might favour the host than the pathogen. The result of this study is in agreement with the findings of Aydinalp and Cresser [21] revealed periodic low soil moisture make plant easily susceptible to diseases. Furrow planting had promising potential of mitigating climate change and reducing disease severity when integrated with intercropping and compost application. Furrow planting was effective when the soil had good water holding capacity similar to soil of Haramaya and less effective in sand soils with high drainage capacity for example soil of Babile.

Compost application reduced the final common bacterial blight disease severity (3.9-17.3) when applied singly and (14.2-36\%) of disease severity reduction when combined with other resilience strategies during 2013 cropping season. The result of this experiment is in agreement with the results of Vallad et al. [31] and Abdasi et al. [32] conducted on foliar plant diseases. Vallad et al. [31] revealed that compost had $34-65 \%$ of disease symptom reduction of bacterial speck of Arabidopsis thaliana caused by Pseudomonas syringae pv. tomato compared with non-amended soil. Abbasi et al. [32] found that application of compost resulted in reduced bacterial spot incidence on tomato fruit by $28-33 \%$, compared with non-amended soil. Disease control with compost has been attributed to successful competition 
Citation: Hailu N, Fininsa C, Tana T, Mamo G (2015) Effect of Climate Change Resilience Strategies on Common Bacterial Blight of Common Bean (Phaseolus vulgaris L.) in Semi-arid Agro-ecology of Eastern Ethiopia. Essential Oil. J Plant Pathol Microb 6: 310. doi:10.4172/21577471.1000310

for nutrients by beneficial microorganisms, antibiotic production by beneficial microorganisms and activation of disease-resistant genes in plants. Using compost not only could supply plant nutrients, but also can increase tolerance and resistance to diseases and retains soil moisture [33]. Composts' contribution to nutrient fertility must also be taken into account because nutrient effects may influence the severity of pathogens and consequently reduce greenhouse gas emission largely carbon dioxide emission as the result of carbon sequestration [19].

When the climate change strategies are integrated their synergetic effect significantly reduced disease severity, AUDPC and disease progress rate. Row intercropping + compost application and row intercropping + compost application + furrow planting have shown significant difference in disease severity reduction compared to less integrated climate change resilience strategies and sole planted plots at Babile and Haramaya. Compost application aggravated the diseases severity on the susceptible variety of Mexican 142 when applied solely, at Haramaya during both cropping seasons. This was because of compost application could have enhanced the growth of Mexican 142 variety at fast rate and created closed canopy earlier, consequently increased temperature and humidity, which sequentially could create favorable condition for common bacterial blight development and spread. Generally, there were higher disease progress rates on Mexican 142 than on Gofta during both seasons and both locations. When composting and furrowing are integrated to intercropping, they are highly effective in reducing disease severity, disease progress rate and the AUDPC as the result of synergetic effect.

Comparisons of disease progress rates among climate change resilience strategies, between varieties, locations and cropping seasons have shown different trends when compared to disease severity and AUDPC. The resilience strategies having lower disease severity exhibited higher disease progress rate. High disease rates were observed in some of resilience strategies that had lower disease severity. This could be due to high density of initial inoculum from the infected seeds, infested debris or infested soil that might have increased the initial disease severity. The disease progress rate with higher initial disease severity was higher even though there was lower final disease severity. Experimental studies have shown that the number of initial inoculum [34] considerably influenced the rates of disease increase. In an experiment with southern blight of processing carrot, the rate of disease increase generally increased as the number of initial foci increased [35].

Generally, common bacterial blight severity was reduced due to the reduction of inoculum dispersal and inhibition of inoculum proliferation and creating disfavoring conditions for the bacteria by climate change resilience strategies. These climate change resilience strategies of disease management therefore are cheaper, sustainable and could be easily adopted by small-scale farmers in eastern Ethiopia. The results obtained from this study suggested the importance of climate change resilience strategies applied singly and in combination as management option of common bacterial blight and other common bean diseases in the eastern Ethiopia and in areas with similar agroecological conditions. The furrow preparation and compost application rate of common bean should also need further investigation in the study area.

\section{Conclusions and Recommendations}

Application of integrated climate change resilience strategies in field experiments enhanced productivity of common bean and reduced disease severity and AUDPC of common bacterial blight compared to solely applied climate change strategies and sole planting common beans over locations and seasons. In addition, the most integrated strategy: row intercropping + compost application + furrow planting, has shown promising results in maintaining soil temperature and moisture. Thus, it could be concluded that farmers in eastern Ethiopia should design a strategy to promote common bean production through the application of row intercropping + compost application + furrow planting and row intercropping + compost application to improve the physico-chemical properties of soil and sustain enhanced production and productivity of common bean. It is strongly believed that integrated climate change strategies through reducing CBB disease epidemics as ecofriendly disease management option and enhancing soil fertility management, contribute substantially to the efforts of increasing food production and household food security in the study area.

\section{Competing interests}

The authors declare that they have no competing interests

\section{Acknowledgments}

The authors are grateful to Masresha Lebie, Woinishet Feleke, Birhanu Asfaw, Azeb Tegenu and the late Cholamu Faltamo, field assistants in the School of Plant Sciences of Haramaya University, for their assistance in data collection and fieldwork. We are grateful to Abraham Negash for his help in field data collection during both seasons. The study was financed by Haramaya University Research office.

\section{References}

1. Tana T, Fininsa, C, Worku, W (2007) Agronomic performance and productivity of common bean (Phaseolus vulgaris $\mathrm{L}$.) varieties in double intercropping with maize (Zea mays L.) in eastern Ethiopia. Asian J Plant Sci 6: 749-756.

2. Katungi E, Farrow A, Chianu J, Sperling L, Beebe S (2009) Base line research Report on Common bean in Eastern and Southern Africa: a situation and outlook analysis of targeting breeding and delivery efforts to improve the livelihoods of the poor in Drought prone areas. ICRISAT, Kampala, Uganda.

3. Amin M, Fitsum S, Selvaraj T, Mulugeta N (2014) Field Management of Anthracnose (Colletotrichum lindemuthianum) in Common Bean through Fungicides and Bioagents. Adv Crop Sci \& Techno 2: 124-129.

4. Fininsa C, Tefera $T$ (2002) Inoculum sources of bean anthracnose and their effect on bean epidemics and yield. Trop Sci 42: 30-34.

5. Fininsa C, Yuen J (2002) Temporal progression of bean common bacterial blight (Xanthomonas campestris pv. phaseoli) in sole and intercropping systems. Eur J Plant Patho 108: 485-495.

6. Lemessa F, Sari W, Wakjira M (2011) Association between angular leaf spot (Phaeoisariopsis griseola (Sacco) Ferraris) and common bean (Phaseolus vulgaris L.) Yield Loss at Jimma, Southwestern Ethiopia. Plant Patho J 110: 57-65.

7. Fininsa C, Yuen J (2001) Association of bean rust and common bacterial blight epidemics with cropping systems in Hararghe highlands, eastern Ethiopia. Inter J Pest Mang 47: 211-219.

8. Fininsa C (2003) Relationship between common bacterial blight severity and bean yield loss in pure stand and bean-maize intercropping systems. Inter J Pest Mang 49: 177-185.

9. Fininsa C, Tefera T (2006) Multiple disease resistance in common bean genotypes and their agronomic performance in eastern Ethiopia. Inter J Pest Mang 52: 291-296

10. Abo-Elyousr KA (2006) Induction of systemic acquired resistance against common blight of bean (Phaseolus vulgaris) caused by Xanthomonas campestris pv. Phaseoli. Egyptian J Phytopathol 34: 41-50.

11. Ghini R, Hamada E, Bettiol W (2008) Review on climate change and plant diseases. Scie \& Agri 65: 98-107.

12. IPCC (Inter-governmental Panel on Climate Change) (2007) Climate change: Mitigation. Contribution of working group iii to the fourth assessment report of the intergovernmental panel on climate change. Cambridge University Press New York, USA.EPA (Environmental Protection Authority) (2010) Ethiopia's Vision for a Climate Resilient Green Economy. EPA, Addis Ababa. Ethiopia. 
Citation: Hailu N, Fininsa C, Tana T, Mamo G (2015) Effect of Climate Change Resilience Strategies on Common Bacterial Blight of Common Bean (Phaseolus vulgaris L.) in Semi-arid Agro-ecology of Eastern Ethiopia. Essential Oil. J Plant Pathol Microb 6: 310. doi:10.4172/21577471.1000310

13. Garrett KA, Dendy SP, Frank EE, Rouse MN, Travers SE (2006) Climate change effects on plant disease: genomes to ecosystems. Annu Rev Phytopathol 44: 489-509.

14. Newton AC, Johnson SN, Gregory P (2011) Implications of climate change for diseases, crop yields and food security. Euphytica 179: 3-18.

15. Chakraborty S, Newton AC (2011) Climate change, plant diseases and food security. Plant Pathology 60: 2-14

16. Doll JE, Baranski M (2011) Climate Change and Agriculture. Fact Sheet Series E3149 on Field Crop Agriculture and Climate change. Michigan State University, East Lancing, USA.

17. Gautam RH, Bhardwaj ML, Kumor R (2013) Climate change and its impact on plant diseases. Current Sci 105: 1685-1691.

18. Boland GJ, Melzer MS, Hopkin A, Higgins V, Nassuth A (2004) Climate change and plant diseases in Ontario. Cana J Plant Pathol 26: 335-350.

19. Luske B (2010) Reduced greenhouse gas emissions due to compost production and compost use in Egypt Comparing two scenarios. Louis Bolk Institute, Amestardem, Netherlands.

20. Sullivan P (2004) Soil System Guide on Sustainable Management of Soilborne Plant Diseases with Compost and Organic Amendments. Appropriate Technology Transfer for Rural Areas (ATTRA), California, USA.

21. Aydinalp C, Cresser MS (2008) The effects of global climate change on agriculture. Ameri-Eurasian J Agri \& Environ Sci 3: 672-676.

22. Toulmin C (2011) Prospering Despite Climate Change: New Directions for Smallholder Agriculture. PP 1-25. Paper presented at the international fund for agricultural development (IFAD) conference. 24-25 January 2011. IFAD, Rome. Italy.

23. EARO (Ethiopian Agricultural Research Organization) (2004) Directory of Released Varieties and Their Recommended Cultural practices. EARO, Addis Ababa, Ethiopia.

24. Stutz J, Donahue S, Mintzer E, Cotter A (2003) Technical report on compost in landscaping applications. Tellus Institute, Boston, USA
25. Buruchara R, Mukankusi C, Ampofo K (2010) Bean disease and pest identification and management. pp.1-67. the handbooks for small-scale seed producers. International Centre for Tropical Agriculture (CIAT). Kampala Uganda.

26. CIAT (Centro Internacional De Agricultura Tropical) (1987) Standard System for the Evaluation of Bean Germplasm. CIAT, Cali, Colombia.

27. Madden LV (2006) Botanical epidemiology: some key advances and its continuing role in disease management. Eur J Plant pathol 115: 3-23.

28. SAS (Statistical Analysis System) (2003) SAS/STAT Guide for Personal Computers, Version 9.1 edition. SAS Institute Inc., Cary, NC.

29. Gomez KA, Gomez AA (1984) Statistical Procedures for Agricultural Research 2nd Edition. John Willey and Sons, Inc, New York, USA.

30. Matusso JMM, Mugwe JN, Mucheru-Muna M (2014) Potential role of cereallegume intercropping systems in integrated soil fertility management in smallholder farming systems of Sub-Saharan Africa. Research J Agri \& Enviro. Mang 3: 162-174.

31. Vallad GE, Cooperband L, Goodman RM (2003) Plant foliar disease suppression mediated by composted forms of paper mill residuals exhibits molecular features of induced resistance. Physio \& Mole Plant Pathol 63: 6577 .

32. Abbasi PA, Al-Dahmani J, Sahin F, Hoitink HAJ, Miller SA (2002) Effect of compost amendments on disease severity and yield of tomato in conventional and organic production systems. Plant Disease 86: 156-161.

33. Barker AV, Bryson GM (2006) Comparisons of composts with low or high nutrient status for growth of plants in containers. Soil Sci \& Plant Analy 37 1303-1319.

34. Jeger MJ, Termorshuizen AJ, Nagtzaam MPM, Bosch FV (2004) The effects of spatial distributions of mycoparasites on biocontrol efficacy: a modelling approach. Bioco Sci \& Techno 14: 359-373.

35. Smith VL, Campbell CL, Jankins SF, Benson DM (1998) Effects of host density and number of disease foci on epidemics of southern blight of processing carrot. Phytopathol 78: 595-600. 